\section{YOU WERE ASKING?}

Question: This spring we watched a pair of Robins raise a family of three young. Now what surprised me was that one was pure white. Just before they were ready to fly away, we took the white bird and a second fledgling and kept them under observation in a cage for a short time. Although the parent birds continued to feed them, we did not like to keep them in captivity too long. After we had released them, I noticed the white bird again on several occasions. This is the first time I have seen a white Robin. Is it something unusual? How did it become white? The parents did not discriminate against it. Would it go south with other Robins? Or do you think it would change its colour? - Mrs. Alice Repchinski, Strong Pine, Sask.

Answer: A few abnormally white or albino specimens are turned in to the Museum every year. Lately we have received an albino mouse, skunk, crow, mallard and even a fish. Such freaks are uncommon in most species and the color change may be due to several causes including disease, injury or genetic change. The factors involved are complex and not well understood in every case. There are records of fowls changing from colored to white, and even back to colored again. There is also a record of a Robin originally banded as a normal bird which later turned white. Albino specimens aie always desired for further study and are welcomed by the Museum. Observations as above on the behavior of albinos and the reactions of other birds to them are equally valuable. - R. W. N.

\section{The Blue Jay Bookshelf}

EIGHTY LAND BIRDS TO KNOW By Stuart L. Thompson, Agincourt Ontario, Book Society of Canada Ltd., 1958.

This ninety page book is designed to help the beginner with the when and where of bird study as well as to give him identification clues to eighty birds of the Lower Great Lakes Region. None of the larger birds of prey, water birds and large game birds are included; however, the majority of the birds included are found in .Saskatchewan.

Each bird is illusitrated in blackand-white with special field marks indicated. Information is given as to the size, family, appearance, voice, habitat, range, nesting and food. In addition to this there are short sections dealing with how to observe, where and when to watch, equipment to use, and the taking of field notes.

The most interesting feature of this book is a color identification key to male spring plumage. In condensed form, the name of the bird, the page it is found on, its size, habitat and the general impression it makes are given along with six squares of color for each bird showing the head, sections of the back, wing, tail, breast and side. Here at a glance you can see the color characteristics of each bird in comparison with the other birds listed. This color identification key serves as an index to the birds in the book. This should prove useful to the beginner who finds that with most indexes he has to know what the bird is in the first place in order to look it up and this he doesn't know until he has leafed through the book and found it without any help from the index.

The book has its limitations as a field guide since it covers such a small number of birds. This, however, is perhaps of advantage to the beginner who is likely to find a comprehensive field guide somewhat bewildering and would appreciate something simpler. - Joyce Dew, Saskatchewan Museum of Natural History.

Dry-land nest site of a Western Grebe colony. - By R. W. Nero, F. W. Lahrman F. G. Bard. Reprinted from the Auk, 75:347-349, 1958.

In this item from the Auk, members of the staff of the Saskatchewan Museum of Natural History (Nero, Lahrman, Bard) report on what seems to be the only record in the literature of a dry-land nest site of the Western Grebe. The dryland nesting site on the Isle of Bays in Old Wives Lake 30 miles southwest of Moose Jaw was visited by the Museum party in 1956 and 1957. At the time of the first visit (Aug. 8,1956 ) about 48 nests were found 